\title{
Pemanfaatan Antosianin dari Ekstrak Kol Merah (Brassica oleracea var) sebagai Pewarna Dye-Sensitized Solar Cells (DSSC)
}

\author{
Dinasti Dwi Pratiwi, Risa Suryana, dan Fahru Nurosyid \\ Program Studi Fisika, Fakultas MIPA, Universitas Sebelas Maret, Surakarta \\ dinasty.dp@student.uns.ac.id
}

Received 12-11-2015, Revised 18-01-2016, Accepted 25-01-2016, Published 20-04-2016

\begin{abstract}
A prototype of Dye-Sensitized Solar Cells (DSSC) utilizing anthocyanin extract from red cabbage was fabricated. This study aims to determine the wavelength absorption of dye contributed in highest efficiency. The sandwich structure of DSSC consists of $\mathrm{TiO}_{2}$ as working electrode, carbon layer as counter electrode, anthocyanin dye as photosensitizer, and electrolyte as electron transfer media. The absorbance of dye was characterized using UV-Vis spectrophotometer, the efficiency of DSSC was calculated using I-V Meter Keithley, and the quantum efficiency was characterized using IPCE Measurement System. The absorption of dye anthocyanin of red cabbage is $450 \mathrm{~nm}-580 \mathrm{~nm}$ wavelengths, $I-V$ characteristic curves resulted efficiency of 0,029\%, and IPCE characteristic resulted highest efficiency at wavelength of 420 $\mathrm{nm}$ with efficiency of $0,099 \%$.
\end{abstract}

Keywords: DSSC, anthocyanin, absorbance, efficiency, IPCE

\section{ABSTRAK}

Prototipe Dye-Sensitized Solar Cells (DSSC) telah difabrikasi dengan dye ekstrak antosianin kol merah. Penelitian ini bertujuan mengetahui panjang gelombang serapan dye yang menyumbang efisiensi tertinggi. DSSC dibuat dengan struktur sandwich yang terdiri $\mathrm{TiO}_{2}$ sebagai elektroda kerja, lapisan karbon sebagai elektroda lawan, dye antosianin sebagai fotosensitizer, dan elektrolit sebagai media transfer elektron. Karakterisasi yang dilakukan meliputi, absorbansi dengan spektrofotometer UV-Vis, efisiensi DSSC dengan Keithley I-V Meter, dan efisiensi kuantum dengan IPCE Measurement System. Hasil uji UV-Vis diperoleh absorbansi dye antosianin kol merah pada panjang gelombang $400 \mathrm{~nm}-700 \mathrm{~nm}$. Karakteristik I-V DSSC diperoleh efisiensi sebesar 0,029 \%, dan hasil karakteristik IPCE diperoleh efisiensi tertinggi pada panjang gelombang $420 \mathrm{~nm}$ dengan efisiensi $0,099 \%$.

Kata kunci: DSSC, antosianin, absorbansi, efisiensi, IPCE.

\section{PENDAHULUAN}

Dye-Sensitized Solar Cells (DSSC) adalah sel surya berbasis zat warna yang mampu menyerap cahaya ${ }^{[1]}$. DSSC telah banyak diteliti sebagai sel surya generasi berikutnya karena memiliki struktur sederhana dan harga fabrikasi yang murah ${ }^{[2]}$. Keunggulan lain dari DSSC adalah tidak memerlukan teknologi yang rumit sehingga biaya produksinya relatif murah dan bahan-bahannya pun mudah diperoleh ${ }^{[3]}$.

Komponen DSSC meliputi lapisan semikonduktor pada substrat Transparent Conductive Oxide (TCO) sebagai anoda, katalis pada elektroda lawan sebagai katoda, dye sebagai fotosensitiser, dan elektrolit redoks. Salah satu komponen yang mempengaruhi kinerja 
DSSC adalah dye. Dye berfungsi menyerap energi cahaya matahari yang menghasilkan elektron $^{[4]}$.

Karena peran penting dye, telah banyak dikembangkan berbagai jenis dye sintesis dan alami dalam perkembangan DSSC. Dye sintesis paling efisien menggunakan jenis ruthenium complex yang mampu menghasilkan efisiensi 10\%. Karena penelitian dye sintesis sebelumnya dari Taher et al. menggunakan eosin y, aniline blue, bromophenol blue, alcian blue, methyl orange, crystal violet, fast green, carbol fuchsin memiliki efisiensi yang jauh lebih rendah daripada $\mathrm{Ru}$ complex ${ }^{[5]}$. Meskipun efisiensi yang dihasilkan Ru tinggi, tetapi harga bahan dasar dan biaya produksi dye ini cukup mahal, dye berbasis kompleks sulit dalam pembuatannya, dan mengandung logam berat yang tidak ramah lingkungan. Oleh karena itu, diperlukan dye alami sebagai dye yang ramah lingkungan dan biayanya murah. Beberapa peneliti mengembangkan berbagai dye alami. Calogero et al. telah mencoba pewarna dari jus jeruk sisilia merah sebagai sensitizer dengan efisiensi mencapai $0,66 \%{ }^{[6]}$. Roy et al. mencoba pewarna dari rose bengal sebagai sensitizer dengan efisiensi mencapai $2,09 \%^{[7]}$. Riset yang telah dilakukan di Cina oleh Zhou et al. dengan menggunakan 20 dye alami dari berbagai ekstrak dari bunga, buah, obat-obatan tradisional Cina, dan minuman seperti rhododendron, herba artemisiae scopariae, manggis, dan kopi ${ }^{[8]}$. Ekstrak tersebut berhasil membuktikan bahwa dye alami dapat memberikan efek fotovoltaik. Efisiensi tertinggi terdapat pada ekstrak buah manggis yang menghasilkan sebesar $1,17 \%$. Penelitian dye alami lainnya oleh Taya et al. telah mengekstrak daun segar dan kering dari adas sowa, seledri, ganggang hijau, bayam, dan arugula. Hasil menunjukkan kinerja DSSC yang lebih baik pada daun bayam setelah pengeringan dengan efisien mencapai $0,29 \%{ }^{[9]}$.

Ekstrak dye atau pigmen tumbuhan yang digunakan sebagai fotosensitiser, salah satunya dapat berupa ekstrak antosianin ${ }^{[10]}$. Molekul antosianin memiliki kelompok karbonil dan hidroksil yang terikat pada permukaan semikonduktor $\mathrm{TiO}_{2}$, yang berperan dalam eksitasi dan transfer elektron dari molekul antosianin ke pita konduksi lapisan semikonduktor $\mathrm{TiO}_{2}{ }^{[11]}$. Tim Harvard Forest tahun 2011 telah meneliti bahwa spektrum serapan antosianin bernilai maksimum pada rentang panjang gelombang $450 \mathrm{~nm}-570 \mathrm{~nm}^{[12]}$. Panjang gelombang tersebut termasuk daerah cahaya tampak. Sehingga antosianin dapat digunakan sebagai dye pada DSSC karena bersifat menyerap cahaya tampak yang dihasilkan cahaya matahari. Pada penelitian ini, menggunakan ekstrak antosianin dari kol merah sebagai zat warna alami pada DSSC. Kol merah merupakan salah satu sayuran yang mengandung kaya $\operatorname{antosianin}^{[13]}$. Kol merah mengandung setidaknya 36 dari 300 macam antosianin. Antosianin dari kol merah mempunyai tingkat kestabilan yang baik ${ }^{[14]}$. Menurut Kim dan Wampler (2009), kandungan antosianin pada kol merah sebesar $355 \mathrm{mg} / 100 \mathrm{~g}^{[15]}$.

Penelitian yang dilakukan oleh Maddu et al, nilai absorbansi dye antosianin ekstrak kol merah dapat menangkap spektrum cahaya pada rentang $450 \mathrm{~nm}-570 \mathrm{~nm}$ dengan nilai panjang gelombang maksimum sebesar $530 \mathrm{~nm}$ dan memenuhi syarat sebagai penyerap cahaya matahari ${ }^{[16]}$. Nilai absorbansi panjang gelombang ekstrak kol merah ini cukup lebar dari penelitian yang dilakukan oleh Chang yang mengekstrak daun bayam dan daun buah ipomea dengan nilai panjang gelombang berturut-turut $437 \mathrm{~nm}$ dan $410 \mathrm{~nm}^{[17]}$, dan Fitria yang mengekstrak kulit buah naga dengan nilai panjang gelombang $458 \mathrm{~nm}^{[18]}$. Penelitianpenelitian yang sudah dilakukan berkaitan dengan dye antosianin dari kol merah belum ada yang meneliti tentang sumbangan $d y e$ terhadap efisiensi kuantum. Sampai saat ini belum diketahui pada panjang gelombang berapa serapan dye menyumbang efisiensi tertinggi DSSC. Oleh karena itu, dalam artikel ini dilaporkan panjang gelombang serapan yang menghasilkan efisiensi tertinggi pada DSSC. 


\section{METODE}

Bahan penelitian terdiri dari ekstrak kol merah sebagai dye, kaca FTO Aldrich sebagai substrat, $\mathrm{TiO}_{2}$ sebagai elektroda kerja, karbon sebagai elektroda lawan, dan elektrolit sebagai media transfer elektron. Alat penelitian untuk deposisi $\mathrm{TiO}_{2}$ menggunakan spin coating, alat karakterisasi meliputi UV-Visible Spectrophotometer Lambda 25, Keithley I-V Meter 2602A, dan IPCE Measurement System QEX7 Serial \#150.

Ekstrak antosianin kol merah diperoleh dengan kol merah digerus hingga halus, dilarutkan dengan campuran akuades, methanol, dan asam asetat, selanjutnya dimaserasi selama 24 jam. Ekstrak dye antosianin disaring menggunakan kertas saring. Dye yang sudah diperoleh diuji $U V$-Vis. Fabrikasi DSSC meliputi deposisi elektroda kerja $\mathrm{TiO}_{2}$ pada kaca FTO, elektroda kerja $\mathrm{TiO}_{2}$ direndam pada dye, membuat elektroda lawan dari karbon, dan disusun dalam bentuk struktur sandwich (Gambar 1). Prototipe DSSC diuji $I$ - $V$ meter untuk menghitung efisiensinya dan IPCE Measurement untuk menentukan efisiensi kuantum.

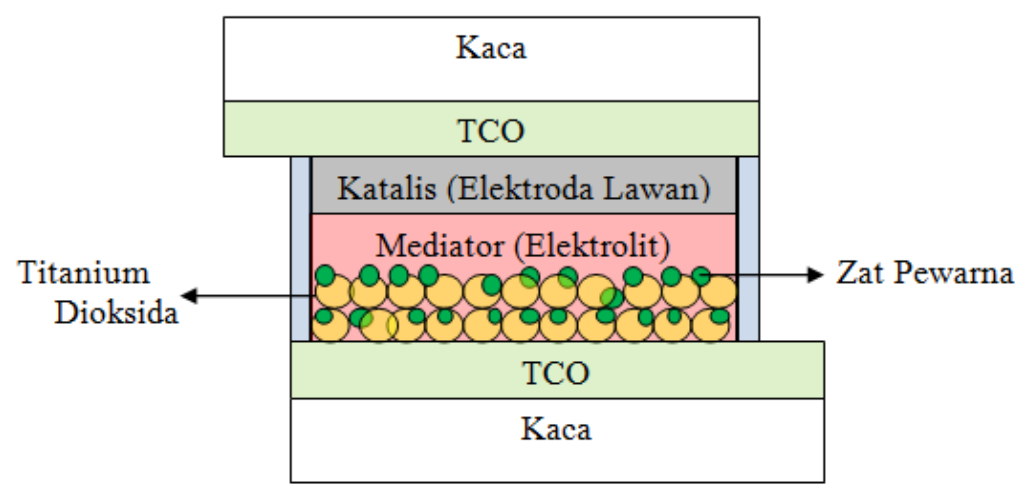

Gambar 1. (Colour online) Struktur sandwich DSSC ${ }^{[19]}$

\section{HASIL DAN PEMBAHASAN}

\section{Karakterisasi Absorbansi Dye}

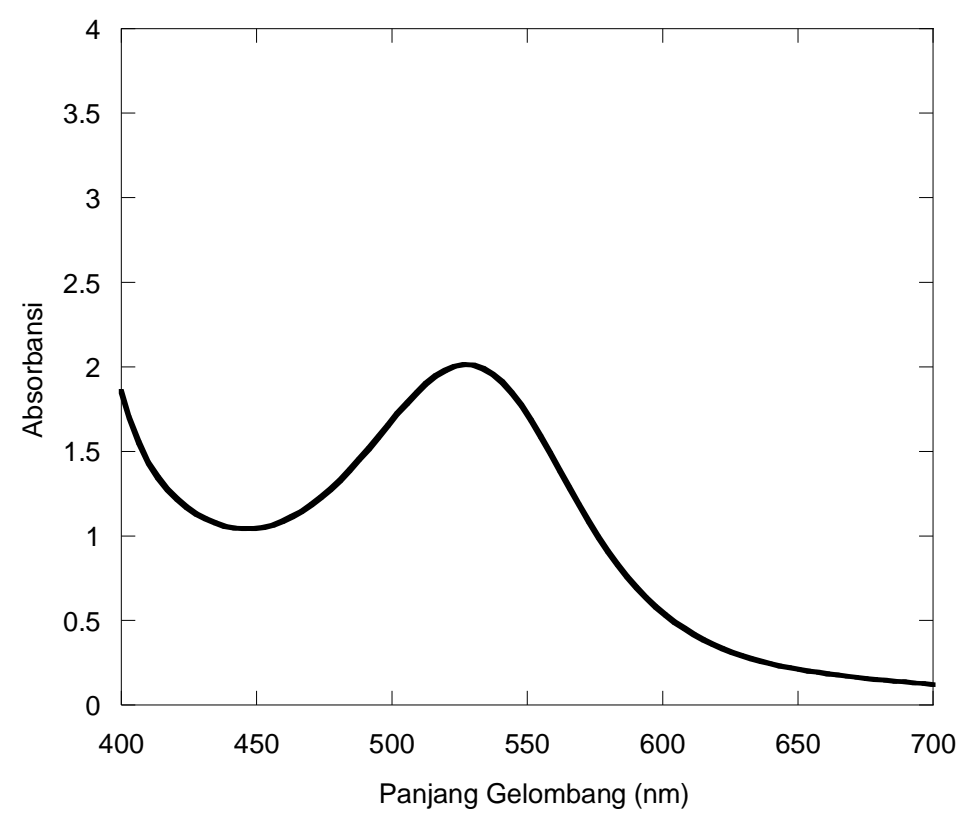

Gambar 2. Grafik Absorbansi Dye Antosianin Ekstrak Kol Merah 
Ekstrak dye sebelum digunakan sebagai sensitizer diuji spektrum absorbansinya dengan menggunakan spektrofotometer $U V$-Visible Lambda 25 dengan rentang panjang gelombang $400 \mathrm{~nm}-700 \mathrm{~nm}$.

Gambar 2 menunjukkan hasil karakterisasi spektrum absorbansi dye antosianin ekstrak kol merah. Gambar tersebut terlihat bahwa serapan cahaya berada pada rentang panjang gelombang $450 \mathrm{~nm}-580 \mathrm{~nm}$ dengan panjang gelombang maksimum ( $\lambda \max ) 530 \mathrm{~nm}$. Data tersebut diketahui bahwa kol merah terbukti memiliki daya absorb pada rentang panjang gelombang cahaya tampak. Hasil ini sesuai dengan penelitian Maddu et al [16].

\section{Karakterisasi I-V DSSC}

Pengukuran arus-tegangan menggunakan Keithley I-V Meter, dilakukan saat kondisi gelap dan terang dengan intensitas cahaya $1000 \mathrm{~W} / \mathrm{m} 2$ dan luasan sel aktif 2 x 10-4 m2. Kurva IV DSSC dengan dye antosianin ekstrak kol merah ditunjukkan pada Gambar 3. Dari hasil karakteristik I-V dapat dihitung daya keluaran, fill factor, dan efisiensi DSSC yang ditunjukkan pada Tabel 1 .

Efisiensi konversi DSSC berkaitan langsung dengan tiga parameter, yaitu Isc (short circuit current), Voc (open circuit voltage), dan FF (Fill Factor). Isc merupakan arus rangkaian pendek yang terjadi ketika tengangan bias sama dengan nol. Arus ini sama dengan jumlah dari foton yang dikonversikan menjadi pasangan elektron-hole. Parameter kedua adalah tegangan rangkaian terbuka (Voc). Voc merupakan potensial maksimum yang dicapai ketika arus tidak mengalir karena semua exciton terekombinasi sehingga dalam DSSC tidak mengalir arus. Parameter ketiga adalah fill factor (FF). Fill factor merupakan luasan efektif yang didapatkan kurva hubungan antara tegangan terhadap arus sel surya. Jika nilai fill factor lebih tinggi dari 0,7 atau 70\% maka sel tersebut lebih baik[20].

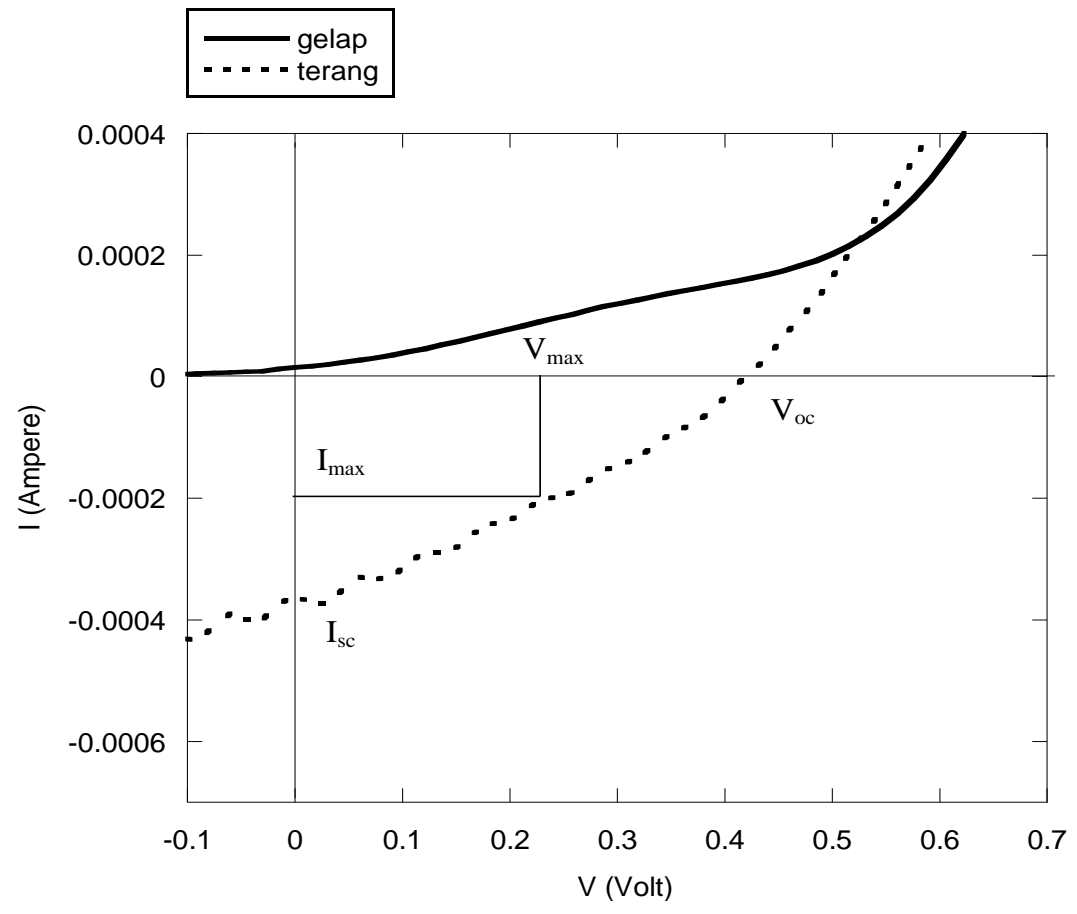

Gambar 3. Grafik $I-V$ DSSC dengan Dye Antosianin Ekstrak Kol Merah 
Tabel 1. Parameter-Parameter DSSC dengan Dye Antosianin Ekstrak Kol Merah

\begin{tabular}{cc}
\hline Karakteristik $I-V$ & Sampel DSSC Dye Antosianin Ektrak Kol Merah \\
\cline { 2 - 2 }$V_{o c}($ Volt $)$ & $4,3 \times 10^{-1}$ \\
$I_{s c}(\mathrm{~A})$ & $3,6 \times 10^{-4}$ \\
$V_{\max }($ Volt $)$ & $2,5 \times 10^{-1}$ \\
$I_{\max }(\mathrm{A})$ & $2,3 \times 10^{-4}$ \\
$P_{\max }($ Watt $)$ & $5,9 \times 10^{-5}$ \\
$F F$ & $3,7 \times 10^{-1}$ \\
$\eta(\%)$ & $2,9 \times 10^{-2}$ \\
\hline
\end{tabular}

Tegangan rangkaian terbuka (Voc) DSSC yang terukur sebesar 0,43 V. Nilai tegangan Voc ini lebih besar dibandingkan penelitian sebelumnya oleh Maddu et al dengan nilai 0,36 V. Arus rangkaian pendek (Isc) yang dihasilkan sebesar 0,36 $\mathrm{mA}$ dan arus maksimum (Imax) sebesar 0,23 mA. Hasil ini juga menunjukkan bahwa nilai arus yang terukur lebih besar dibandingkan penelitian Maddu et al dengan nilai Isc dan Imax masing-masing adalah $0,0072 \mathrm{~mA}$ dan $0,005 \mathrm{~mA}$. Nilai fill factor (FF) dalam penelitian ini masih rendah, yaitu 0,37 dibandingkan dengan penelitian Maddu et al yang mencapai 0,48. Hal tersebut dikarenakan nilai FF dipengaruhi oleh mobilitas elektron. Peningkatan mobilitas elektron akan meningkatkan arus. Dalam penelitian ini, arus keluaran yang dihasilkan masih kecil, sehingga daya maksimum keluaran juga kecil. Hal tersebut disebabkan tidak semua pembawa muatan yang terkoleksi akan menjadi arus (seperti peristiwa rekombinasi). Karena rendahnya arus yang dihasilkan, maka capaian nilai efisiensi konversi juga masih rendah. Nilai efisiensi yang dihasilkan sebesar 0,029\% dan hasil ini lebih rendah dibandingkan dengan penelitian Maddu et al yang mencapai $0,055 \%$. Hal ini dapat disebabkan transpor elektron pada elektroda lawan, dalam penelitian ini menggunakan karbon dari jelaga lilin sedangkan Maddu et al dari lempengan karbon. Selain itu, perbedaan dalam bentuk elektrolit, penelitian Maddu et al menggunakan elektrolit dalam bentuk gel, sedangkan penelitian ini menggunakan elektrolit berupa larutan.

\section{Karakterisasi IPCE DSSC}

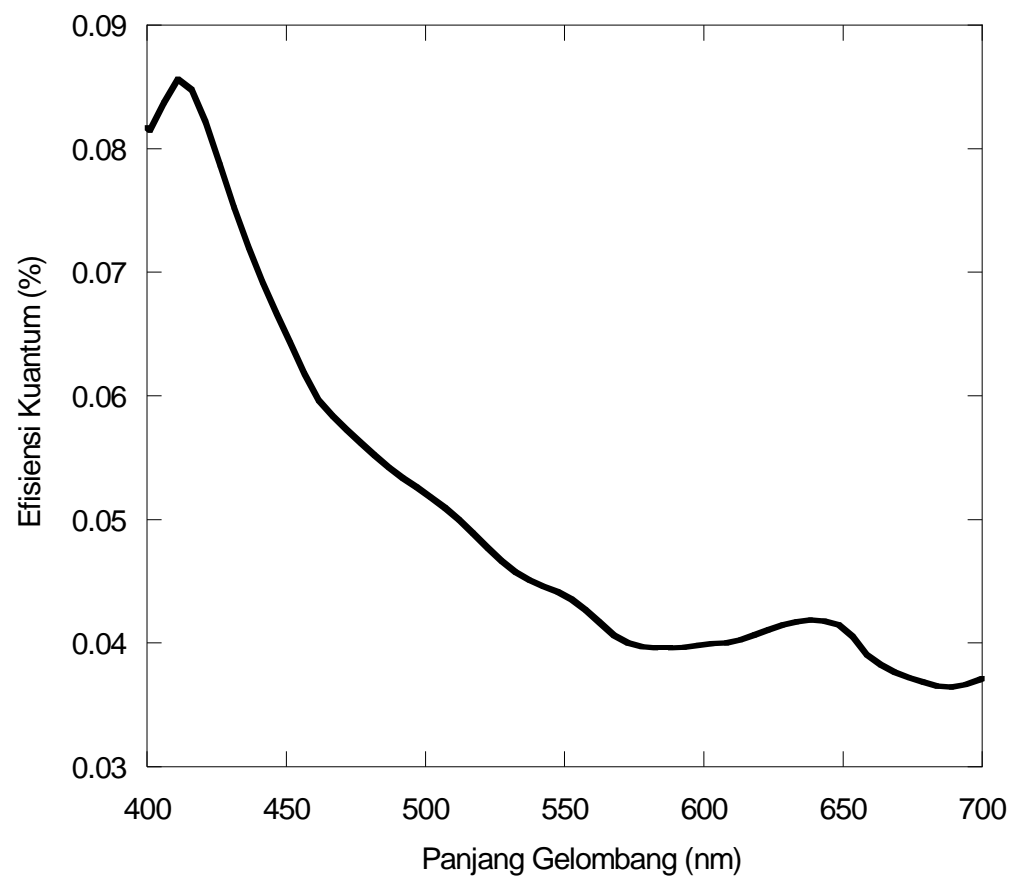

Gambar 4. Grafik IPCE DSSC Dye Antosianin Ekstrak Kol Merah 
Bentuk spektrum IPCE DSSC pada Gambar 4 menunjukkan puncak penyerapan foton terjadi pada panjang gelombang $\pm 400 \mathrm{~nm}$. Artinya, pada daerah panjang gelombang tersebut sumbangan foton yang menghasilkan elektron tertinggi. Jangkauan serapan cahaya ini merupakan daerah serapan $\mathrm{TiO}_{2}$. Hal tersebut dapat disebabkan dye yang teradsorb di $\mathrm{TiO}_{2}$ terlalu sedikit, sehingga kemampuan penyerapan dye antosianin kol merah tidak terlalu dominan, sedangkan serapan cahaya oleh $\mathrm{TiO}_{2}$ lebih dominan. Hal tersebut menyebabkan penyerapan foton di daerah visible semakin menurun [21], padahal lampu yang digunakan pada karakterisasi I-V menghasilkan cahaya tampak, sehingga hasil efisiensi DSSC sangat rendah.

Puncak kurva absorbansi dan puncak spektrum IPCE tidak sama. Pada kurva absorbansi, puncak terletak pada $530 \mathrm{~nm}$ dan puncak spektrum IPCE bergeser ke daerah panjang gelombang $\pm 400 \mathrm{~nm}$. Berdasarkan Govorov et al tahun 2013 dan 2014 bahwa puncak spektrum kuantum efisiensi dan puncak absorbansi tidak pada panjang gelombang yang sama [22,23]. Perbedaan puncak tersebut dapat dikaitkan adanya transfer balik dari eksitasi elektron TiO2 yang terjebak kembali ke daerah UV. Adanya dye dapat dianggap sebagai kontributor negatif (tidak menyumbang dan atau hanya menyumbang sedikit saja) untuk arus foto secara keseluruhan ketika disinari di daerah visible [24].

\section{KESIMPULAN}

Karakteristik absorbansi dye antosianin kol merah menunjukkan serapan cahaya berada pada rentang panjang gelombang $450 \mathrm{~nm}-580 \mathrm{~nm}$ dengan panjang gelombang maksimum ( $\lambda \max ) 530 \mathrm{~nm}$. Kinerja dye-sensitized solar cells memperlihatkan karakteristik I-V diperoleh efisiensi sebesar $0,029 \%$, dan karakteristik IPCE diperoleh efisiensi tertinggi pada panjang gelombang $420 \mathrm{~nm}$ dengan efisiensi 0,099\%. Serapan dye pada daerah visible tidak efektif.

\section{UCAPAN TERIMAKASIH}

Penulis mengucapkan terima kasih kepada DP2M DIKTI dan LPPM UNS atas pendanaan hibah penelitian PUPT (No. kontrak 339/2711/PL/2015).

\section{DAFTAR PUSTAKA}

1. Grätzel, M. 2003. Dye-Sensitised Solar Cells. Journal of Photochemistry and Photobiology, Vol. 4, pp. 145-153.

2. Grätzel, M. 2005. Solar Energy Conversion by Dye-Sensitized Photovoltaic Cells. Inorg Chem, Vol. 44, pp. 6841-6851.

3. O'regan, B., and Grätzel, M. 1991. Low-Cost, High-Efficiency Solar Cell Based on Dye Sensitized Colloidal $\mathrm{TiO}_{2}$ Films. Nature, Vol. 353, pp. 737-740.

4. Chiba, Y., Islam, A., Watanab, Y., Komiya, R., Koide, N., and Han, L. 2006. DyeSensitized Solar Cells with Conversion Efficiency of 11.1\%. Japanese Journal of Applied Physcics, Vol. 45, pp. 1638-1640.

5. El-Agez, T.M., Taya, S.A., Elrefi, K.S., and Abdel-Latif, M.S. 2014. Dye-Sensitized Solar Cells Using Some Organic Dyes as Photosensitizers. Optica Applicata, XLIV, Vol. 2, DOI: $10.5277 /$ oa140215.

6. Calogero, G., and Marco, G. 2008. Red Sicilian Orange and Purple Egg Plant Fruits as Natural Sensitizers for Dye-Sensitized Solar Cells. Solar Energy Materials and Solar Cells, Vol. 92, No. 1, pp. 1341-1346. 
7. Roy, M., Balraju, P., Kumar, M., and Sharma, G. 2008. Dye-Sensitized Solar Cells Based on Rose Bengal Dye and Nanocrystalline $\mathrm{TiO}_{2}$. Solar Energy Materials and Solar Cells, Vol. 92, No. 2, pp. 909-913.

8. Zhou, H., Wu, L., Gao, Y., and Ma, T. 2011. Dye-Sensitized Solar Cells Using 20 Natural Dyes as Sensitizers. Journal of Photochemistry and Photobiology, Vol. 219, No. 2, pp. 188-194.

9. Taya, S., El-Agez, T., El-Ghamri, H., and Abdel-Latif, M. 2013. Dye-Sensitized Solar Cells Using Fresh and Dried Natural Dyes. International Journal of Materials Science and Applications, Vol. 2, No. 2, pp. 37-42.

10. Wongcharee, K., Meeyoo, V., and Chavadej, S. 2007. Dye-Sensitized Solar Cells using Natural Dyes Extracted from Rosella and Blue Pea Flowers. Solar Energy Materials and Solar Cells, Vol. 91, pp. 566-571.

11. Ludin, N.A., Al-Alwani, M.A.M., Mohamad, A.B., Kadhum, A.H., Sopian, K., \& Abdul, K.N.S. 2014. Review on the Development of Natural Dye Photosensitizer for Dye Sensitized Solar Cells. Renewable Sustainable Energy Rev, 31, 386-96.

12. Tim Harvard Forest. 2011. Leaf Pigments. Cambridge : Fakultas Ilmu Seni, Universitas Harvard.

13. Giusti, M. M \& Wrolstad, R. E. 2003. Characterization and Measurement of Anthocyanins by UV Spectroscopy. USA : John Wiley and Sons.

14. Tra, T. T. 2003. Stability of These Anthocyanin Extract from Several Plants in Vietnam. Proceeding Vietnam International Conference Food and Technology, 83-93.

15. Kim, Y. \& Wampler, D.J. 2009. Anthocyanin Content in Various Anthocyanin Rich Fruits and Vegetables. SENSUS.

16. Maddu, A., Zuhri, M., \& Irmansyah. 2007. Penggunaan Ekstrak Antosianin Kol merah sebagai Fotosensitizer pada Sel Surya $\mathrm{TiO}_{2}$ Nanokristal Tersensitisasi Dye. Makara Teknologi, 11(2), 78-84.

17. Chang, H., Wu, Chen, Huang, J., \& Lo. 2010. Dye-Sensitized Solar Cells Using Natural Dyes Extracted from Spinach and Ipomoea. Journal of Alloys and Compounds, 495, 606-610.

18. Fitria, J., Adha, Fany, Sahat, \& Tri. 2012. Studi Pemanfaatan Kulit Buah Naga sebagai Materi Sel Surya dengan Metode Dye Sensitized Solar Cell. Laporan PKMP, Jurusan Teknik Material dan Metalurgi ITS.

19. Chappel, S., Grinis, L., Ofir, A., \& Zaban, A. 2005. Extending the Current Collector into the Nanoporous Matrix of Dye Sensitized Electrodes. Journal of Physical Chemistry B, 109, 1643-1647.

20. Hansen, A.D. 2000. Model for a Stand-Alone PV System. Roskilde : Riso National Laboratory.

21. Hoffmann M.R., Martin, S.T., Choi, W., \& Bahnemann, D.W. 1995. Enviromental Applications of Semiconductor Photocatalysis. Chem. Rev. 95, 69-96.

22. Govorov, A.O., Zhang, H., \& Gun'ko, Y.K. 2013. Theory of Photoinjection of Hot Plasmonic Carriers from Metal Nanostructures into Semiconductors and Surface Molecules. J Phys Chem C, 117(166), 16-31.

23. Govorov, A.O., Zhang, H., Demir, H.V., \& Gun'ko, Y.K. 2014. Photogeneration of Hot Plasmonic Electrons with Metal Nanocrystals: Quantum Description and Potential Applications. Nano Today, 9, 85-101.

24. Brennan, L.J., Milton, F.P., Salmeron, A.S., Zhang, H., Govorov, A.O., Fedorov, A.V., \& Gun'ko, Y.K. 2015. Hot Plasmonic Electrons for Generation of Enhanced Photocurrent in Gold-TiO ${ }_{2}$ Nanocomposites. Nanoscale Research Letters, DOI 10.1186/s11671-014-0710-5 